\title{
Heterogeneous Echotexture
}

National Cancer Institute

\section{Source}

National Cancer Institute. Heterogeneous Echotexture. NCI Thesaurus. Code C69214.

A description of heterogeneous density elements seen in a tissue composition image

obtained by sonography. 